\title{
ANALISIS HUKUM SURAT EDARAN WALIKOTA PADANGSIDIMPUAN NOMOR 511.I/ 5900/ 2018 TENTANG PENGGUNAAN LPG BERSUBSIDI TABUNG 3 KILOGRAM BAGI USAHA KECIL MIKRO DAN RUMAH TANGGA DI KOTA PADANGSIDIMPUAN
}

\author{
Dedy Suhendra ${ }^{1)}$, Muhammad Faisal ${ }^{2)}$ \\ Universitas Muhammadiyah Tapanuli Selatan \\ dedy.suhendra@um-tapsel.ac.id ${ }^{1)}$ \\ muhammad.faisal@um-tapsel.ac.id ${ }^{2)}$
}

\begin{abstract}
Abstrak
Gas LPG merupakan salah satu kebutuhan pokok masyarakat pada saat ini, apalagi sejak berjalannya Program Pemerintah tentang Konversi Minyak Tanah ke Gas LPG pada tahun 2007. Perbedaan harga antara LPG bersubsidi dan non subsidi tersebut sering dimanfaatkan oleh para pelaku pasar, maupun oknum yang tidak bertanggungjawab untuk menjual LPG $3 \mathrm{Kg}$ kepada pihak-pihak yang tidak seharusnya dengan harga yang lebih tinggi, ataupun ulah para pengoplos LPG $3 \mathrm{Kg}$ ke Tabung 12 $\mathrm{Kg}$, bahkan cenderung menyebabkan kelangkaan LPG 3 Kilogram Bersubsidi di pasaran. Pemerintah Kota Padangsidimpuan, dalam mnelaksanakan tugasnya untuk melindungi kepentingan masyarakat terhadap kebutuhan Gas LPG $3 \mathrm{Kg}$, mengambil sebuah kebijakan dengan mengeluarkan Surat Edaran Walikota Padangsidimpuan Nomor 511.I/ 5900/ 2018 tentang Penggunaan LPG Bersubsidi Tabung 3 Kilogram Bagi Usaha Kecil Mikro dan Rumah Tangga di Kota Padangsidimpuan. Adapun yang menjadi tujuan penelitian ini adalah Untuk mengetahui kedudukan surat edaran yang dikeluarkan oleh Pemerintah dalam Tatanan Hukum Indonesia dan bagaimana kekuatan hukum Surat Edaran Walikota Padangsidimpuan Nomor 511.I/ 5900/ 2018 tentang Penggunaan LPG Bersubsidi Tabung 3 Kilogram Bagi Usaha Kecil Mikro dan Rumah Tangga di Kota Padangsidimpuan berdasarkan Sistim Perundang-Undangan yang Berlaku di Negara Republik Indonesia.
\end{abstract}

Kata kunci : Analisis Hukum, LPG Bersubsidi, Surat Edaran.

\begin{abstract}
Liquefied Petroleum Gas (LPG) is one of the basic needs of the community at this time, especially since the Government Program on Conversion of Kerosene to LPG in 2007. The difference in price between subsidized and non-subsidized LPG is often used by market participants, as well as persons who are not responsible for sell LPG $3 \mathrm{~kg}$ to parties that should not be at a higher price, or act of LPG $3 \mathrm{~kg}$ pengoplos to $12 \mathrm{~kg}$ tubes, and even tend to cause the scarcity of subsidized LPG 3 Kilograms on the market. Padangsidimpuan City Government, in carrying out its duties to protect the interests of the community against the needs of $3 \mathrm{Kg}$ LPG Gas, adopted a policy by issuing Circular Letter of Padangsidimpuan Mayor No. 511.I / 5900/2018 concerning the Use of 3 Kilogram-Subsidized LPG Tubes for Micro and Household Small Businesses in Padangsidimpuan City. The purpose of this research is to determine the position of the circular issued by the Government in the Indonesian Legal Order and how the legal strength of Padangsidimpuan Mayor Circular Letter Number 511.I / 5900/2018 concerning the Use of Subsidized LPG 3 Kilogram Tubes for Micro and Household Small Businesses in the City of Padangsidimpuan based on the Legislation System in force in the Republic of Indonesia
\end{abstract}

Keywords: Legal Analysis, Subsidized LPG, Circular.

\section{PENDAHULUAN}

Pemerintah dalam melaksanakan

tugas dan fungsinya sebagai pelayan masyarakat berusaha semaksimal mungkin agar bisa melindungi kepentingan dan kebutuhan masyarakatnya, baik kebutuhan 
sandang, pangan, pemeliharaan serta perlindungan kepentingan umum lainnya. Untuk mendukung terlaksananya usahausaha pemerintah tersebut diatas, maka diterbitkanlah Undang-Undang Administrasi Pemerintahan Nomor 30 tahun 2014, yang didalamnya ada memuat tentang Azas-Azas Umum Pemerintahan yang Baik (AUPB), AUPB meliputi asas kepastian hukum, kemanfaatan, ketidakberpihakan, kecermatan, tidak menyalahgunakan kewenangan, keterbukaan, kepentingan umum dan pelayanan yang baik. Sehingga dalam mengambil suatu keputusan atau kebijakan, pemerintah harus bertindak sesuai dengan AUPB.

Gas LPG merupakan salah satu kebutuhan pokok masyarakat pada saat ini, apalagi sejak berjalannya Program Pemerintah tentang Konversi Minyak Tanah ke Gas LPG pada tahun 2007. Dimana tujuan dari konversi minyak tanah ke LPG ini adalah :

1. Melakukan diversifikasi pasokan energy untuk mengurangi ketergantungan terhadap BBM.

2. Mengurangi penyalahgunaan minyak tanah bersubsidi

3. Melakukan efisiensi anggaran pemerintah

4. Menyediakan bahan bakar yang praktis, bersih dan efisien

Akan tetapi hal ini menyebabkan meningkatnya kebutuhan dan penggunaan Gas LPG, baik untuk keperluan rumah tangga maupun keperluan usaha, kalau sebelumnya masyarakat Indonesia terbiasa dengan penggunaan minyak tanah untuk keperluan memasak, maka terpaksa beralih ke LPG. Agar masyarakat kurang mampu juga bisa memakai LPG, pemerintah memutuskan memberikan kompor dan tabung LPG $3 \mathrm{Kg}$ secara gratis.

Terkait tentang penyediaan, pendistribusian, dan penetapan harga LPG tabung $3 \mathrm{Kg}$ diatur dalam Peraturan Presiden Republik Indonesia Nomor 104 tahun 2007 dan Peraturan Menteri ESDM No. 26 Tahun 2009 tentang penyelenggaraan penyediaan dan pendistribusian LPG Tabung $3 \mathrm{Kg}$. Pada pasal 20 ayat (2) disebutkan "Pengguna
LPG Tertentu sebagaimana dimaksud pada ayat (1) merupakan konsumen rumah tangga dan usaha mikro yang menggunakan LPG Tertentu dalam kemasan tabung LPG $3 \mathrm{Kg}$ dengan harga diatur dan ditetapkan oleh Menteri (2009; 11). Harga LPG $3 \mathrm{Kg}$ berbeda dengan harga LPG pengguna umum, karena LPG $3 \mathrm{Kg}$ disubsidi oleh pemerintah, sedangkan yang bukan tabung $3 \mathrm{Kg}$ adalah non subsidi. Untuk Kota Padangsidimpuan Harga Eceran tertinggi (HET) diatur didalam Surat Keputusan Walikota Nomor 59/ KPTS/ 2017 tentang Penetapan Harga Eceran Tertinggi Liquefied Petroleum Gas Tabung 3 Kilogram di Kota Padangsidimpuan, yang menyebutkan bahwa harga ditingkat agen adalah Rp.14.000,- dan ditingkat penyalur Rp. 16.000,-

Akibat perbedaan harga antara LPG bersubsidi dan non subsidi tersebut sering dimanfaatkan oleh para pelaku pasar, maupun oknum yang tidak bertanggungjawab untuk menjual LPG 3 $\mathrm{Kg}$ kepada pihak-pihak yang tidak seharusnya dengan harga yang lebih tinggi, ataupun ulah para pengoplos LPG 3 $\mathrm{Kg}$ ke Tabung $12 \mathrm{Kg}$ yang harganya lebih mahal sehingga para pengoplos mendapat untung yang lebih banyak, seperti yang diberitakan oleh Harian Metro Tabagsel terbitan tanggal 28 Nopember 2018, Polres Padang Sidempuan telah berhasil menangkap pelaku pengoplosan LPG $3 \mathrm{Kg}$ berinisial ZS (43) di Perumahan Sidimpuan Lestari Indah Kelurahan Palopat Kecamatan Padangsidimpuan Tenggara. Polisi berhasil menyita alat bukti berupa 3 Selang Regulator , 1 Timbangan 20 Kilogram , Segel LPG , Karet Pengaman Kepala Tabung Gas, Sarung Tangan, Jumlah tabung Gas LPG 3 Kilogram sebanyak 270 tabung, Tabung Gas LPG 5,5 Kilogram sebanyak 10 tabung, Tabung Gas LPG 12 Kilogram sebanyak 12 tabung dan 1 unit Mobil Pick Up BK 9435 VP. Inilah salah satu penyebab langkanya LPG $3 \mathrm{Kg}$ sehingga harganya naik diatas Harga Eceran tertinggi (HET).

Pemerintah

Kota

Padangsidimpuan, dalam mnelaksanakan tugasnya untuk melindungi kepentingan masyarakat terhadap kebutuhan Gas LPG 
$3 \mathrm{Kg}$, mengambil sebuah kebijakan dengan mengeluarkan Surat Edaran Walikota Padangsidimpuan Nomor 511.I/ 5900/ 2018 tentang Penggunaan LPG Bersubsidi Tabung 3 Kilogram Bagi Usaha Kecil Mikro dan Rumah Tangga di Kota Padangsidimpuan.

Dengan keluarnya Surat Edaran ini ternyata menimbulkan berbagai tanggapan dan reaksi dari masyarakat, baik antara masyarakat, maupun melalui media sosial. Sebagian orang beranggapan bahwa tindakan Walikota ini adalah tindakan setengah hati dalam membela kepentingan rakyat kecil, karena seharusnya yang diharapkan rakyat adalah tindakan langsung pemerintah terhadap penertiban penggunan Gas LPG $3 \mathrm{Kg}$ sesuai dengan ketentuan yang sudah ada, bukan dengan mengeluarkan Surat Edaran.

Oleh karena hal tersebut diatas, maka penulis tertarik untuk melakukan penelitian dengan judul Analisis Hukum Surat Edaran Walikota Padangsidimpuan Nomor 511.I/ 5900/ 2018 tentang Penggunaan LPG Bersubsidi Tabung 3 Kilogram Bagi Usaha Kecil Mikro dan Rumah Tangga di Kota Padangsidimpuan

\section{METODE}

Penelitian ini menggunakan metode deskriptif analitis, yaitu suatu metode penelitian dengan mengungkapkan masalah, mengolah data, menganalisis, meneliti, dan menginterpretasikan serta membuat kesimpulan dan member saran yang kemudian disusun pembahasannya secara sistematis sehingga masalah yang ada dapat dipahami. Guna mengetahui dan membahas suatu permasalahan, dengan kata lain penelitian merupakan upaya pencarian yang amat bernilai edukatif (Amiruddin, 2014; 19).

Berdasarkan perumusan masalah, spesifikasi penelitian ini menggunakan penelitian hukum normatif atau doktrinal yang juga disebut sebagai penelitian perpustakaan atau studi dokumen, karena lebih banyak dilakukan terhadap data yang bersifat sekunder yang ada di perpustakaan, bersifat deskriptif analisis.

$$
\text { Dalam penelitian normatif, }
$$

pengumpulan data antara lain melalui studi kepustakaan yang dilakukan dengan cara mengumpulkan dan mempelajari bahan hukum primer (pimary source), bahan hukum sekunder (secondary sources), dan bahan hukum tersier. Bahan hukum primer merupakan bahan hukum memiliki otoritas (authority) artinya bersifat mengikat (Dyah Ochtorina Susanti, 2014; 52), dalam penelitian ini yang menjadi bahan hukum primer terdiri atas Undang-Undang Dasar, UndangUndang, Peraturan dan Surat Edaran Walikota Padangsidimpuan Nomor 511.I/ 5900/ 2018 yang berkaitan dengan pokok masalah yang diteliti. Sedangkan bahan hukum sekunder yaitu bahan yang memberikan penjelasan mengenai bahan hukum primer, seperti rancangan undang-undang, hasil-hasil penelitian, pendapat para pakar hukum (Amiruddin, 2014; 32).

\section{PEMBAHASAN \\ Kedudukan Surat Edaran Yang Dikeluarkan Oleh Pemerintah Dalam Tatanan Hukum Indonesia}

Fungsi dari tata hukum adalah memberikan tempat yang sebenarnya terhadap hukum tersebut, sehingga hukum tersebut tersusun dengan baik sesuai dengan tertib aturan hukum, ketentuan yang berlaku dan dapat diterapkan untuk menyelesaikan segala peristiwa hukum yang terjadi. Menurut Mochtar Kusumaatmadja hukum yang dibuat harus sesuai dan harus memperhatikan kesadaran hukum masyarakat. Hukum tidak boleh menghambat modernisasi. Hukum agar dapat berfungsi sebagai sarana pembaruan masyarakat hendaknya harus ada legalisasi dari kekuasaan Negara.

Lahirnya tata hukum Indonesia sejalan dengan berdirinya Negara Republik Indonesia, hal ini tercantum dalam Pembukaan Undang-Undang Dasar 1945, yang berbunyi "Atas berkat Rahmat Allah Yang Maha Kuasa dan dengan didorongkan oleh keinginan luhur, supaya berkehidupan kebangsaan yang bebas, maka rakyat Indonesia menyatakan dengan ini kemerdekaannya," "Kemudian daripada itu disusunlah Kemerdekaan Indonesia itu dalam suatu Undang-Undang Dasar Negara Indonesia". UUD hanyalah memuat ketentuan-ketentuan dasar dan merupakan rangka dari Tata Hukum Indonesia. Sehingga masih diperlukan lagi 
berbagai macam peraturan perundangundangan organik lainnya.

Dalam hukum positif di Indonesia, terdapat macam-macam tata hukum di Indonesia antara lain sebagai berikut:

1. Hukum Tata Negara, adalah ketentuanketentuan yang mengatur mengenai organisasi dalam mencapai tujuannya dalam kemasyarakatan

2. Hukum Administrasi Negara, adalah ketentuan-ketentuan yang mengatur mengenai pengelolaan administrasi pemerintahan yang jika dalam arti luas bertujuan dalam mengetahui cara tingkah laku negara dan alat-alat perlengkapan Negara

3. Hukum Perdata adalah ketentuanketentuan yang mengatur dan membatasi setiap tingkah laku manusia untuk memenuhi kepentingan (kebutuhan)nya atau mengatur kepentingan-kepentingan seseorang.

4. Hukum Pidana adalah ketentuanketentuan yang mengatur dan membatasi tingkah laku setiap manusia dalam meniadakan pelanggaran kepentingan umum

5. Hukum Acara atau Hukum Formal adalah peraturan hukum yang mengatur mengenai cara bagaimana mempertahankan dan menjalankan peraturan hukum materal. Tata hukum Acara atau hukum formal dibagi menjadi dua antara lain:

a. Hukum acara pidana adalah ketentuan-ketentuan yang mengatur dalam cara bagaimana pemerintah menjaga kelangsungan pelaksanaan hukum pidana material

b. Hukum acara perdata adalah ketentuan-ketentuan yang mengatur mengenai cara bagaimana mempertahankan dan menjalankan mengenai peraturan hukum perdata material

Tata hukum Indonesia terdiri atas aturan-aturan hukum yang tersusun sedemikian rupa, saling berhubungan, saling menentukan. yang memuat norma hukum yang mengikat secara umum dan dibentuk atau ditetapkan oleh lembaga negara atau pejabat yang berwenang melalui prosedur yang ditetapkan dalam Peraturan Perundang-undangan (pasal 1 ayat 2 Undang-Undang No. 12 tahun 2011 tentang Pembentukan Peraturan Perundang-undangan).

Peraturan perundang-undangan di Indonesia bersifat hirarkis, dimana peraturan yang lebih rendah berlaku, bersumber, berdasar pada norma yang lebih tinggi, dan peraturan perundangan yang lebih rendah tidak boleh bertentangan dengan peraturan yang lebih tinggi tingkatannya.

Hirarki Peraturan perundangundangan di Indonesia diatur dalam pasal 7 ayat (1) Undang-Undang No. 12 tahun 2011 tentang Pembentukan Peraturan Perundang-undangan adalah sebagai berikut:

1. Undang-Undang Dasar Negara Republik Indonesia Tahun 1945;

2. Ketetapan Majelis Permusyawaratan Rakyat;

3. Undang-Undang/Peraturan Pemerintah Pengganti Undang-Undang;

4. Peraturan Pemerintah;

5. Peraturan Presiden;

6. Peraturan Daerah Provinsi; dan

7. Peraturan Daerah Kabupaten/Kota.

Pembuatan peraturan perundangundangan memerlukan proses dan prosedur yang bisa saja memerlukan waktu yang lama, sementara kebutuhan dan kepentingan manusia modern berkembang secara dinamis/ cepat , karena pada umumnya manusia adalah makhluk yang tak pernah merasa puas. Jadi tidak mungkin peraturan perundangundangan mampu mengatur segala aspek kepentingan manusia. Kejadian tersebut menunjukan bahwa sewaktu-waktu hukum memang dihadapkan pada situasi yang "luar biasa". Apapun juga yang terjadi dan dihadapi, hukum tidak dapat berhenti dan menolak untuk bekerja, semata-mata berdasarkan alasan, bahwa ia tidak dipersiapkan untuk itu (Satjipto Rahardjo. $2010: 23$ ).

\begin{tabular}{lrr} 
Indonesia sebagai & penganut \\
konsep Welfare & State & $\begin{array}{r}\text { (Negara } \\
\text { Kesejahteraan), }\end{array}$ \\
pemerintah harus & \multicolumn{2}{c}{ secara akibatkan }
\end{tabular}


mensejahterakan warga negaranya, karena itu pemerintah diberi juga freies erness., Tercakup dalam arti freies ernessen ini ialah membuat peraturan tentang hal-hal yang belum ada pengaturannya, atau mengimplementasikan peraturan yang sesuai dengan kenyataan, yang disebut dengan discretionary power. Selain itu Pemerintah mempunyai droit function yaitu kekuasaan untuk menafsirkan (baik memperluas maupun mempersempit) sendiri mengenai ketentuan-ketentuan yang bersifat enusiatif (S.F. Marbun \& Moh. Mahfud MD. 2006 : 46-47).

Campur tangan pemerintah ini merupakan kebebasan bertindak yang diatur menurut undang-undang maupun peraturan pelaksana lainnya. Sehingga pemerintah sering menempuh berbagai langkah kebijaksanaan tertentu, antara lain menciptakan peraturan kebijaksanaan (beleidsregel, policy rule). Produk semacam peraturan ini tidak terlepas dari kaitannya dengan penggunaan freies ermessen (Philipus M. Hadjon, 2001; 152).

Penggunaan freies ermessen tidak boleh bertentangan dengan hukum yang berlaku baik tertulis maupun tidak tertulis dan juga hanya ditujukan demi kepentingan umum, menurut Philipus $M$. Hadjon pejabat tata usaha negara yang bersangkutan merumuskan itu dalam berbagai bentuk juridische regel seperti halnya peraturan, pedoman, pengumuman, surat edaran dan mengumumkan kebijaksanaan itu $(2001 ; 152)$.

Surat Edaran diklasifikasikan kedalam bentuk quasi legislation yang berisi norma-norma aturan yang bersifat administratif yang berfungsi sebagai petunjuk atau pedoman kerja, yang menurut Pedoman Tata Naskah Dinas Instansi Pemerintah yang dikeluarkan oleh Menteri Pendayagunaan Aparatur Negara Dan Reformasi Birokrasi Republik Indonesia tahun 2012 ditegaskan bahwa Surat Edaran adalah naskah dinas yang memuat pemberitahuan tentang hal tertentu yang dianggap penting dan mendesak. Kewenangan untuk menetapkan dan menandatangani surat edaran oleh pejabat pimpinan tertinggi instansi pemerintah dapat dilimpahkan kepada pejabat pimpinan sekretariat instansi pemerintah atau pejabat yang ditunjuk sesuai dengan substansi surat edaran. Pendistribusian surat edaran disampaikan dengan surat dinas/ memorandum/ nota dinas dari pejabat yang berwenang kepada pejabat dan pihak terkait lainnya.

Surat edaran bertujuan menampakkan keluar suatu kebijakan tertulis namun tanpa disertai kewenangan pembuatan peraturan dari badan atau pejabat tata usaha negara yang menciptakan peraturan kebijaksanaan tersebut. Suparjati menyebutkan bahwa "Isi surat edaran yang berasal dari suatu instansi pemerintah/ swasta dapat berupa suatu anjuran, larangan, pemberitahuan, petunjuk, dan sebagainya, dan dapat dipergunakan sebagai dasar untuk mengambil suatu kebijaksanaan lebih lanjut" (200; 39).

Maka berdasarkan penjelasan tersebut diatas, kedudukan surat edaran bukanlah merupakan bagian dari tata hukum Indonesia yang masuk dalam lingkup hirarki peraturan perundangundangan, karena surat edaran tidak ditujukan untuk umum, tapi hanya untuk kepentingan internal pemerintah saja, yang berfungsi untuk mempenjelasan dan memberi petunjuk tentang cara melaksanakan hal tertentu yang dianggap penting dan mendesak, bukan merupakan produk hukum atau peraturan perundangan-undangan yang mengikat secara umum. Surat edaran hanyalah merupakan suatu kebijakan dari pejabat yang tidak memiliki akibat hukum apapun.

Walaupun surat edaran tidak berhubungan langsung dengan masyarakat atau umum, tetapi terkadang surat edaran tersebut secara tidak langsung berfungsi untuk mempercepat pelaksanaan suatu kebijakan pemerintah yang berhubungan dengan kepentingan masyarakatnya. Seperti yang disampaikan oleh Bagir Manan bahwa kekuatan mengikat dari peraturan kebijakan tidak langsung mengikat secara hukum, tetapi mengandung relevansi hukum. Karena pembuat peraturan kebijakan tidak mempunyai kewenangan perundangundangan. Peraturan kebijakan pada 
dasarnya ditujukan kepada administrasi negara sendiri, jadi yang pertama melaksanakan ketentuan yang termuat dalam peraturan kebijaksanaan adalah badan atau pejabat administrasi negara. Meskipun demikian, ketentuan tersebut secara tidak langsung akan dapat mengenai secara umum.

Kekuatan hukum Surat Edaran Walikota Padangsidimpuan Nomor 511.I/ 5900/ 2018 tentang Penggunaan LPG Bersubsidi Tabung 3 Kilogram Bagi Usaha Kecil Mikro dan Rumah Tangga di Kota Padangsidimpuan berdasarkan Sistim Perundang-Undangan yang Berlaku di Negara Republik Indonesia

Walikota Padangsidimpuan Irsan Efendi Nasution menerbitkan Surat Edaran (SE) Nomor: 511.1/5900/2018 tertanggal 6 Nopember 2018 tentang Penggunaan LPG Bersubsidi Tabung 3 Kilogram Bagi Usaha Kecil Mikro dan Rumah Tangga di Kota Padangsidimpuan, yang isinya antara lain :

Mengacu kepada Peraturan

Presiden Nomor 104 tentang

Penyediaan Pendistribusian dan

Penetapan Harga Liquefied

Petrolium Gas (LPG) Bersubsidi Tabung 3 Kilogram Yang Diperuntukkan Bagi Pelaku Usaha Kecil Mikro dan Rumah Tangga, maka bersama ini kami sampaikan hal-hal sebagai berikut:

1. Liquefied Petrolium Gas (LPG) Bersubsidi Tabung 3 Kilogram diperuntukkan bagi masyarakat yang berhak, yaitu tergolong keluarga Pra Sejahtera/ Kurang Mampu ataupun Masyarakat Miskin

2. Mengimbau seluruh Aparatur Sipil Negara (ASN) di Lingkungan Pemerintah kota Padangsidimpuan untuk tidak menggunakan LPG bersubsidi, dan kepada seluruh kepala Organisasi Perangkat Daerah (OPD) agar mensosialisasikan pada masing-masing jajarannya.

3. Kepada para Camat se-Kota Padangsidimpuan agar mengimbau seluruh masyarakat/ Pelaku Usaha yang ada diwilayah saudara baik Usaha di Bidang Perhotelan, Rumah Makan, Restoran, Usaha Kecil , Menengah dan Besar yang memiliki Aset diatas Rp.50.000.000,- agar tidak menggunakan LPG Bersubsidi Tabung 3 Kilogram

4. Untuk Para Pangkalan LPG Bersubsidi yang berada di Kota Padangsidimpuan agar:

a. Tidak mendistribusikan LPG Bersubsidi 3 Kilogram langsung ke pengecer

b. Wajib mengutamakan masyarakat Rumah Tangga Akhir

c. Pangkalan dilarang keras mengecer keliling

d. Dilarang keras menyalahgunakan isi tabung LPG Bersubsidi

e. Menjual LPG Bersubsidi sesuai Harga Eceran Tertinggi (HET) yang telah ditetapkan, dan mentaati ketentuan peraturan perundang-undangan yang berlaku

5. Apabila tidak mengindahkan Surat Edaran ini, maka kami akan beri sanksi, bahkan hingga pencabutan izin usahanya.

6. Setiap pangkalan wajib memenuhi segala persyataran, baik fasilitas maupun peralatan dan keamanan lainnya. Seperti:

a. Bangunan harus memiliki ventilasi yang cukup, serta ada tanda larangan merokok

b. Memasang papan nama pangkalan serta harga HET sesuai standar di lokasi pangkalannya, sehingga mudah dilihat oleh masyarakat umum.

c. Menyediakan Racun Api/ Cap/ Stempel pangkalan, Timbangan dan bak 
pendeteksi kebocoran LPG Bersubsidi 3 Kilogram.

Dilihat berdasarkan isi dari surat edaran tersebut diatas, maka ditinjau dari Sistim Perundang-Undangan yang berlaku di Negara Republik Indonesia kekuatan hukum dari surat edaran tersebut tidaklah memiliki kekuatan hukum yang mengikat secara umum, karena tidak memuat norma hukum yang mengikat secara umum, sesuai dengan yang tercantum dalam Undang-Undang Nomor 12 tahun 2011 tentang Pembentukan Peraturan Perundang-Undangan pada pasal 1 ayat (2) menyebutkan bahwa "Peraturan Perundang-undangan adalah peraturan tertulis yang memuat norma hukum yang mengikat secara umum dan dibentuk atau ditetapkan oleh lembaga negara atau pejabat yang berwenang melalui prosedur yang ditetapkan dalam Peraturan Perundang-undangan".

Materi muatan dari surat edaran tersebut tidak bersifat mengatur (regeling) secara umum dan abstrak, hal ini bisa kita lihat dari isi surat edaran tersebut. Van Kreveld juga mengatakan, walaupun didasarkan pada azas freies ermessen, beleidsregel harus memenuhi syarat-syarat tertentu untuk kemudian dapat berlaku, antara lain:

1. Tidak dapat bertentangan dengan peraturan dasar yang mengandung wewenang diskresioner yang dijabarkannya;

2. Tidak dapat bertentang dengan nalar sehat;

3. Harus dipersiapkan dengan cermat, kalau perlu meminta advis teknis dari instansi yang berwenang, rembukan dengan para pihak yang terkait dan mempertimbangkan alternatif yang ada;

4. Isi kebijakan harus jelas memuat hak dan kewajiban warga masyarakat yang terkena dan ada kepastian tindakan yang akan dilakukan oleh instansi yang bersangkutan (kepastian hukum formal);
5. Pertimbangan tidak harus rinci, asalkan jelas tujuan dan dasar pertimbangannya; dan

6. Harus memenuhi syarat kepastian hukum materiil, artinya hak yang telah diperoleh dari warga yang terkena harus dihormati, kemudian harapan yang telah ditimbulkan jangan sampai diingkari.

Sedangkan didalam surat edaran tersebut tidak memuat tentang hak dan kewajiban warga masyarakat yang terkena dampaknya, serta tidak ada kepastian tindakan yang akan dilakukan oleh instansi yang bersangkutan (kepastian hukum formal). Sehingga pemerintah tidak bisa mempergunakan surat edaran ini sebagai alat untuk menindak pihak-pihak atau orang yang melakukan pelanggaran terkait dengan hal-hal yang dilarang menurut surat edaran ini. Seperti yang disampaikan oleh ibu Nurlailasari selaku Kabid Perdagangan di Dinas Peradagangan Kota Padangsidimpuan bahwa:

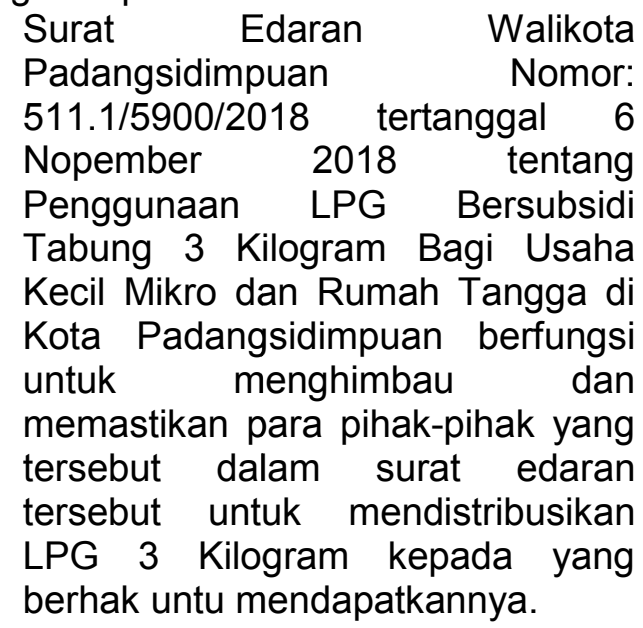

Hal senada juga disampaikan oleh ibu Elizar selaku staf di Bagian Hukum kantor Walikota Padangsidimpuan, bahwa:

Fungsi dari surat edaran hanyalah himbauan semata kepada pihakpihak yang tersebut dalam surat edaran tersebut, sehingga tidak bisa ditindak apabila ada yang melanggarnya.

Oleh karena itu menurut Armen Hasibuan, selaku pengguna LPG 3 Kilogram, bahwa: 
Seharusnya Walikota bukan mengeluarkan Surat Edaran, tetapi mengajukan pembuatan Perda terkait pendistribusian LPG bersubsidi di Kota Padangsidimpuan, sehingga aparat terkait memiliki payung hukum yang jelas untuk menindak orang atau pihak yang melakukan pelanggaran terkait pendistribusian atau penggunaan LPG bersubsidi

Karena sebagaimana disampaikan oleh Ramlan selaku pengecer LPG 3 Kilogram, bahwa:

Tidak ada pengaruh dari dikeluarkannya surat edaran Walikota tersebut, karena sampai dengan saat ini, LPG tersebut harganya masih mahal, tidak sesuai HET yang ditetapkan oleh pemerintah, bahkan tidak jarang LPG tersebut susah untuk didapatkan, dan kami juga masih bebas mengecer LPG tersebut.

Kemudian apabila ditinjau dari bentuk surat edaran tersebut, maka berdasarkan Pedoman Tata Naskah Dinas Instansi Pemerintah yang dikeluarkan oleh Menteri Pendayagunaan Aparatur Negara Dan Reformasi Birokrasi Republik Indonesia tahun 2012 ditegaskan bahwa Surat Edaran adalah naskah dinas yang memuat pemberitahuan tentang hal tertentu yang dianggap penting dan mendesak, dengan susunan surat edaran terdiri dari :

1. Kepala surat edaran terdiri dari:

2. Batang Tubuh

Bagian batang tubuh surat edaran terdiri dari:

1) alasan tentang perlunya dibuat surat edaran;

2) peraturan perundangundangan atau naskah dinas lain yang menjadi dasar pembuatan surat edaran;

3) pemberitahuan tentang hal tertentu yang dianggap mendesak.

3. Kaki, bagian kaki surat edaran terdiri dari:
1) tempat dan tanggal penetapan;

2) nama jabatan pejabat penanda tangan;

3) tanda tangan pejabat penanda tangan;

4) nama lengkap pejabat penanda tangan, yang ditulis dengan huruf kapital;

5) cap dinas

Pendistribusian surat edaran disampaikan dengan surat dinas/ memorandum/ nota dinas dari pejabat yang berwenang kepada pejabat dan pihak terkait lainnya.

Sedangkan didalam Surat Edaran Walikota Padangsidimpuan Nomor: 511.1/5900/2018, pada bagian batang tubuh tidak ada disebutkan alasan yang menyebabkan dianggap perlunya untuk mengeluarkan surat edaran tersebut dan pemberitahuan tentang hal tertentu yang dianggap mendesak. Hal ini bertentangan dengan yang sudah ditetapkan oleh Pedoman Tata Naskah Dinas Instansi Pemerintah yang dikeluarkan oleh Menteri Pendayagunaan Aparatur Negara Dan Reformasi Birokrasi Republik Indonesia. Seharusnya Walikota selaku pelaksana pemerintahan di tingkat daerah harus mengikuti apa yang telah ditetapkan oleh pemerintah melalui Menteri Pendayagunaan Aparatur Negara Dan Reformasi Birokrasi Republik Indonesia, sehingga surat edaran tersebut berfungsi secara efektif dan efisien, dan tidak cacat hukum, karena bentuknya tidak sesuai dengan aturan yang telah dietapkan

\section{SIMPULAN}

Kesimpulan dari penelitian ini adalah:

1. Kedudukan surat edaran yang dikeluarkan oleh Pemerintah dalam Tatanan Hukum Indonesia bukanlah merupakan bagian dari Tata Hukum Indonesia yang masuk dalam lingkup hirarki peraturan perundangundangan, karena surat edaran tidak ditujukan untuk umum, tapi hanya untuk kepentingan internal pemerintah saja, yang berfungsi untuk mempenjelasan dan memberi petunjuk 
tentang cara melaksanakan hal tertentu yang dianggap penting dan mendesak.

2. Surat Edaran Walikota Padangsidimpuan Nomor 511.I/ 5900/ 2018 tentang Penggunaan LPG Bersubsidi Tabung 3 Kilogram Bagi Usaha Kecil Mikro dan Rumah Tangga di Kota Padangsidimpuan berdasarkan Sistim Perundang-Undangan yang berlaku di Negara Republik Indonesia tidaklah memiliki kekuatan hukum yang mengikat secara umum, karena surat edaran tidak memuat norma hukum yang mengikat secara umum, sesuai dengan yang tercantum dalam Undang-Undang Nomor 12 tahun 2011, tidak memuat tentang hak dan kewajiban warga masyarakat yang terkena dampaknya, serta tidak ada kepastian tindakan yang akan dilakukan oleh instansi yang bersangkutan (kepastian hukum formal). Kemudian Pada bagian batang tubuh Surat Edaran Walikota Padangsidimpuan tersebut tidak ada disebutkan alasan yang menyebabkan dianggap perlunya untuk mengeluarkan surat edaran tersebut dan pemberitahuan tentang hal tertentu yang dianggap mendesak

\section{SARAN}

Saran penulis dalam penelitian ini adalah:

1. Sebaiknya freies ermessen yang dimiliki oleh pemerintah diimplemtasikan dalam bentuk peraturan yang memuat norma hukum, sehingga mengikat secara umum, bukan hanya sekedar surat edaran.

2. Pemerintah Kota Padangsidimpuan dalam membuat surat edaran sebaiknya berpedoman kepada Pedoman Tata Naskah Dinas Instansi Pemerintah yang dikeluarkan oleh Menteri Pendayagunaan Aparatur Negara Dan Reformasi Birokrasi Republik Indonesia.

\section{REFERENSI}

Abdul Razak, 2005. Kedudukan dan Fungsi Peraturan Kebijakan tentang Perizinan dalam Rangka
Penyelenggaraan Pemerintahan.

Disertasi: Program Pascasarjana Fakultas Hukum Unhas,

Amiruddin dan Zainal Asikin. 2014. Pengantar Metode Penelitian Hukum. Jakarta: Rajawali Press,

Asshiddiqie, Jimly. 2011. Perihal UndangUndang. Jakarta: Rajawali Pers

Azhary.1995.Negara Hukum Indonesi. Jakarta: UI-Press,

E. Utrecht.1988. Pengantar Hukum Administrasi Negara Indonesia. Surabaya: Pustaka Tinta Mas

Hadjon, Philipus M,dkk. 2001. Pengantar Hukum Administrasi Indonesia. Yogyakarta: Gadjah Mada University Press

Harijanti, Susi Dwi. 2011. Negara Hukum Yang Berkeadilan, Pusat Studi Kebijakan Negara. Bandung: FH UNPAD

Imanuel, Victor. 2013. Konsep Uji Materil. Malang: Setara Press

Jimly Asshiddiqie. 1997. Teori \& Aliran Penafsiran Hukum Tata Negara. Jakarta: Ind. Hill.Co.

Koentjoro, Diana Halin. 2004. Hukum Administrasi Negara, Bogor: Ghalia Indonesia

Kamisa, Dra. 1997. Kamus Besar Bahasa Indonesia. Surabaya: Cahaya Agency,

Manan, Bagir dan Kunta Magnar. 1997. Beberapa Masalah Hukum Tata Negara Indonesia. Bandung: Alumni,

Manan, Bagir. 2004. Hukum Positif Indonesia (Satu Kajian Teoritik). Jakarta: FH UII Press

Marzuki, Laica. 2010. Peraturan Kebijakan (Beleidsregel): Hakikat serta Fungsinya Selaku Sarana Hukum 
Pemerintahan, Jakarta: Penerbit Universitas Trisakti

Mochtar Kusumaatmadja, 1970, Fungsi dan Perkembangan Hukum dalam Pembangunan Nasional, Bandung: Bina Cipta

Pantja, I Gde \& Suprin Na'a. 2008. Dinamika Hukum dan IImu Perundang-Undangan di Indonesia. Bandung: PT. Alumni

Prasetya, Hendrawan. 2009. Business Letters. Yogyakarta: Pustaka Grhatama

Satjipto Rahardjo. 2010 "Penegakan Hukum Progresif". Jakarta: Penerbit Kompas

Suparjati, Dra, dkk. 2000, Surat-Menyurat Dalam Perkantoran. Yogyakarta: Kanisius

Susanti, Dyah Ochtorina dan A`an Efendi. 2014. Penelitian Hukum (Legal Research). Jakarta: Sinar Grafika,

Sibuea, Hotma P. 2010, Asas Negara Hukum, Peraturan Kebijakan, dan Asas- asas Umum Pemerintahan yang Baik, Jakarta: Penerbit Erlangga

Soerjono Soekanto dan Mustafa Abdullah, 1987, Sosiologi Hukum dalam Masyarakat, Jakarta: Rajawali Press

Rahadjo, Satjipto. 2000. Ilmu Huku. Bandung: Citra Aditya Bakti,

Undang-Undang Dasar Negara Republik Indonesia Tahun 1945

\section{Algemene wet Bestuursrecht}

Undang-Undang Nomor 12 tahun 2011 tentang Pembentukan Peraturan Perundang-Undangan

Undang-Undang Nomor 23 tahun 2014 tentang Pemerintahan Daerah
Undang-Undang Nomor 30 tahun 2014 tentang Administrasi Pemerintahan

Menteri Pendayagunaan Aparatur Negara Dan Reformasi Birokrasi Republik Indonesia Menteri Pendayagunaan Aparatur Negara Dan Reformasi Birokrasi Republik Indonesia. 2012. Pedoman Tata Naskah Dinas Instansi Pemerintah. Jakarta: Sekretariat Menpan-RB

Marbun, Rocky. Surat Edaran Kapolri: Serial Kegaduhan Hukum, https://forumduniahukumblogku.wor dpress.com/2015/11/06/suratedara n-kapolri serial-kegaduhan-hukum (diakse tanggal 28 Nopember 2018) 